\title{
ABC transporters in CSCs membranes as a novel target for treating tumor relapse
}

\author{
Laura Zinzi ${ }^{1}$, Marialessandra Contino ${ }^{1 *}$, Mariangela Cantore ${ }^{2}$, Elena Capparelli ${ }^{1}$, Marcello Leopoldo ${ }^{1,2}$ \\ and Nicola A. Colabufo ${ }^{1,2}$
}

1 Dipartimento di Farmacia-Scienze del Farmaco, Università degli Studi di Bari "A. Moro," Bari, Italy

2 Dipartimento di Farmacia-Scienze del Farmaco, Biofordrug srl, Spin-off of University of Bari, Bari, Italy

\section{Edited by:}

Stefania Nobili, University of

Florence, Italy

Reviewed by:

Nathan Thomas Ihle, Pfizer, USA

Andrea Lapucci, University of

Florence, Italy

*Correspondence:

Marialessandra Contino,

Dipartimento di Farmacia-Scienze del Farmaco, Università degli Studi di Bari "A. Moro," Via Orabona 4, 70125 Bari, Italy

e-mail: marialessandra.contino@ uniba.it
CSCs are responsible for the high rate of recurrence and chemoresistance of different types of cancer. The current antineoplastic agents able to inhibit bulk replicating cancer cells and radiation treatment are not efficacious toward CSCs since this subpopulation has several intrinsic mechanisms of resistance. Among these mechanisms, the expression of ATP-Binding Cassette $(A B C)$ transporters family and the activation of different signaling pathways (such as Wnt/ $\beta$-catenin signaling, Hedgehog, Notch, Akt/PKB) are reported. Therefore, considering $\mathrm{ABC}$ transporters expression on CSCs membranes, compounds able to modulate MDR could induce cytotoxicity in these cells disclosing an exciting and alternative strategy for targeting CSCs in tumor therapy. The next challenge in the cure of cancer relapse may be a multimodal strategy, an approach where specific CSCs targeting drugs exert simultaneously the ability to circumvent tumor drug resistance ( $\mathrm{ABC}$ transporters modulation) and cytotoxic activity toward CSCs and the corresponding differentiated tumor cells. The efficacy of suggested multimodal strategy could be probed by using several scaffolds active toward MDR pumps on CSCs isolated by tumor specimens.

Keywords: CSCs, MDR, TICs markers, HTS, P-gp

\section{INTRODUCTION}

The emerging concept about tumorigenesis is that cancer lesions are organized in a hierarchy of heterogeneous cell populations displaying different biological properties and tumorigenic potentials (Lorico and Rappa, 2011). Among these populations, only a small portion, the cancer stem cell or tumor-initiating cell (CSC/TIC) subpopulation is able to induce tumor formation and growth, leading to differentiated cells, the bulk of the tumor. In 1977 Hamburger and Salmon suggested the "CSC theory" by hypothesizing that cancer originates from uncommon cells, CSCs, showing pluripotency and self-renewal (Hamburger and Salmon, 1977; Boman and Wicha, 2008). In 1997 Lapidot and coworkers identified CSCs in leukemia on the basis of cell-surface-markers expression (Lapidot et al., 1994). The discovery of CSCs in leukemia and in several solid tumors, such as breast carcinoma (Al-Hajj et al., 2003; Hemmati et al., 2003; Singh et al., 2003; Carla et al., 2005; Fang et al., 2005; Xin et al., 2005; Lawson et al., 2007; Li et al., 2007; Ricci-Vitiani et al., 2007), was the proof of the CSC theory in cancer development.

CSC/TICs are characterized by the following properties: (a) production of all types of cells in a tumor, including CSC/TICs and non-CSC/TICs; (b) unlimited self-renewal and division capacity; (c) quiescence or slow proliferation, and (d) resistance to conventional antineoplastic therapy (Clevers, 2011). Moreover, recent studies have demonstrated that CSC/TIC phenotypes such as self-renewal and pluripotency are acquired by the activation of oncogenic genes or the inactivation of tumor suppressor genes
(Baccelli and Trumpp, 2012). Since CSCs are characterized by specific surface markers, this subpopulation of cells can be isolated from mixed tumorigenic and non-tumorigenic tumor cells, by different methods of immune selection. CD44 targeting is used in the treatment of acute myeloid leukemia (AML) (Jin et al., 2006), CD24 targeting is for the treatment of colon and pancreatic cancer (Sagiv et al., 2008) and CD133 is targeted for the treatment of hepatocellular and gastric cancer (Smith et al., 2008). The current antineoplastic agents, able to inhibit bulk replicating cancer cells, and radiation treatment are not efficacious toward CSCs and, therefore, targeting these cells could be an helpful strategy for eradicating tumors more efficiently.

However, CSCs possess several intrinsic mechanisms of resistance to current chemotherapeutic drugs. Among these mechanisms, the expression of ATP-Binding Cassette (ABC) transporters family (An and Ongkeko, 2009; Calcagno et al., 2010; Fuchs et al., 2010; Clevers, 2011; Moitra et al., 2011; Pietras, 2011) and the activation of different signaling pathways such as Wnt $/ \beta$-catenin signaling (Teng et al., 2010; Yeung et al., 2010; Takebe et al., 2011; Janikowa and Skarda, 2012), Hedgehog (Hh), Notch (Kobune et al., 2009; Wang et al., 2009; Zhao et al., 2009; Takebe et al., 2011; Janikowa and Skarda, 2012; Jiang et al., 2012), Akt/PKB, ATR/CHK1 survival pathways (Ma et al., 2008; Korkaya et al., 2009; Jiang et al., 2012) and constitutive activation of NF- $\kappa$ B are reported (Zhou et al., 2008; Liu et al., 2010).

The first of these mechanisms is the overexpression of $\mathrm{ABC}$ transporters such as $\mathrm{P}$-glycoprotein (P-gp), Breast Cancer 
Resistance Protein (BCRP), and Multidrug Resistance-associated Proteins (MRPs) that use the energy of ATP hydrolysis to extrude compounds out of cells (Colabufo et al., 2010). These proteins are overexpressed in several tumors and, since responsible for drug efflux, are the main cause of MultiDrug Resistance (MDR) (Colabufo et al., 2010). Among these transporters, P-gp is the mostly studied and is localized in the luminal membrane of endothelial cells constituting the Blood-Brain Barrier (BBB), Blood-CerebroSpinal Fluid Barrier (B-CSF), and BloodTestis Barrier (BTB); thus P-gp exerts a protective function in our body (Pharm et al., 2008; Colabufo et al., 2010). BCRP as P-gp monomer, is considered a "half-transporter" and it effluxes the same P-gp substrates (Pharm et al., 2008; Colabufo et al., 2010). MRPs differ from P-gp for the presence of an additional and specific five transmembrane domain and it efflux organic ions with high molecular weight (Pharm et al., 2008; Colabufo et al., 2010).

Since several antineoplastic drugs are substrates of ABC transporters, one of the strategy to reverse MDR is the use of inhibitors toward these pumps and their co-administration with antineoplastic agents (Perez-Tomas, 2006; Teodori et al., 2006; GimenezBonafe et al., 2008). However, when antineoplastic drugs and P-gp inhibitors are co-administrated, an increased toxicity has been observed because, at the same time, the protective role of P-gp is abolished (Coley, 2010).

Over the last decade, our research group has developed P-gp ligands with different scaffolds displaying different P-gp intrinsic activities (Colabufo et al., 2008a,b, 2009, 2013; Contino et al., 2012, 2013a,b; Nesi et al., 2014). Therefore, considering ABC transporters expression on CSCs membranes, compounds able to modulate MDR activity could induce cytotoxicity in these cells disclosing an exciting and alternative strategy for targeting CSCs in tumors therapy.

\section{CSCS BIOMARKERS}

CSCs display several cell surface markers and their detection is useful for the identification of CSCs in tumors. In addition, the development of antibodies or antibody constructs toward these markers is also suggested as a therapeutic strategy to target CSCs (Kwon and Shin, 2013).

\section{CD133 AND ALDH1}

CD133 and ALDH1 have been identified as markers of TICs in primary human ovarian tumors (Landen et al., 2010). CD133 has been also identified as surface marker to characterize adult stem/progenitor cells in human thyroid glands (Thomas et al., 2006). ALDH1 and CD133 are also markers for the identification of CSCs in colorectal carcinoma (CRC) (Zhou et al., 2014). CD133, together with CD44, is a specific cell-surface marker of prostate cancer (Wang et al., 2013a).

\section{CD44, CD117, CD24}

The hyaluronic acid (HA) receptor CD44 and the stem cell factor receptor CD117 are specific surface markers of ovarian CSC/TICs (Zhang et al., 2008). CD44+CD117+ cells isolated from human ovarian adenocarcinomas represent a subpopulation with an ovarian tumor-initiating capacity, that, injected in mice, induce original tumors from which they are derived (Zhang et al.,
2008). CD24+ cells, isolated from patient tumor specimens, are enriched in ovarian CSC/TICs and have stem-like properties, such as chemoresistance, self-renewal and differentiation (Gao et al., 2010).

\section{METHODS FOR THE ISOLATION OF CSCS}

Fluorescence-Activated Cell Sorting (FACS) is a magnetic cell separation method used to isolate CSCs based on the expression of specific cell surface markers, such as CD24, CD44, and CD133 (Wright et al., 2008; Takaishi et al., 2009). The detection can be performed with specific antibodies in flow cytometry, competitive ELISA (cELISA) or magnetic beads (Dobbin and Landen, 2013). Xia and coworkers have developed humanized antibodies toward the surface marker CD133 that was detected by cELISA (Xia et al., 2013). However the limitation of surface markers recognition is that the results can be ascribed to the specific studied population. Therefore, a second method, represented by the detection of the activity of a specific protein such as the membrane pump ABCG2 or ALDH1A1 enzyme, seems to be more useful than markers recognition alone. The first technique uses the DNA-binding dye Hoechst 33342, originally developed for bone marrow cells (Goodell et al., 1996). This fluorescent dye, used to identify a Hoechst-negative CSC "side population" (Kondo et al., 2004), has been successfully employed to isolate stem cells from solid tissues such as skeletal muscle, lung, liver, testis, kidney, skin, mammary gland and brain (Challen and Little, 2006). This method allows to select the cells displaying an increase in the Hoechst 33342 efflux, ABCG2-mediated, from the nucleus. The limitation of this method is due to the dye toxicity (Siemann and Keng, 1986; Erba et al., 1988).

The high ALDH activity described for CSCs suggested also this enzyme as a probe to isolate these cells. Aldefluor, an ALDH1 substrate, initially used for the isolation of hematopoietic stem cells by FACS (Storms et al., 1999; Cheung et al., 2007) and for CSCs separation in tumor tissue and cancer cell lines (Moreb, 2008; Jiang et al., 2009), has been successfully used for ALDH1 activity detection of CSCs in lung (Jiang et al., 2009), prostate (Li et al., 2010), breast (Charafe-Jauffret et al., 2010), colon (Huang et al., 2009a), and bladder (Su et al., 2010). Aldefluor contains the ALDH1 substrate BODIPYaminoacetaldehyde (BAAA), that is converted into the fluorescent metabolite BODIPY-aminoacetate (BAA) by ALDH1 (Storms et al., 1999). BAA is then retained in living cells, because of its charge and also because Aldefluor inhibits the multidrugresistance transporters. Therefore, Aldefluor-treated cells, with high ALDH1 activity, display high fluorescence and can be isolated by FACS into two subpopulations: ALDH-hi and ALDHlow (Moreb, 2008). This method has been validated for some cancers but it has not been widely employed because of some limitations due to cells handling that can induce stress, disrupt gene expression, and lead to altered cell physiology (Orfao and Ruiz-Arguelles, 1996). To overcome these limitations, the use of Adelfluor staining has been assessed in adherent cell cultures, that resulted in the attached-cell Aldefluor method (ACAM). ACAM displays several advantages since single-cell imaging of physiological processes in CSCs is easier in monolayers than in cells suspension or tumorsphere cultures that are usually used for 
growing CSCs (Fael Al-Mayhani et al., 2009; Pollard et al., 2009; Hirschhaeuser et al., 2010).

CSCs have also been usually sorted into SP cells using UV excitation $(\lambda=350 \mathrm{~nm})$ but the limitation of this method was the cell damage caused by UV radiation exposure. Tomiyasu et al. reported a new method in which CSCs have been sorted by a violet laser $(\lambda=407 \mathrm{~nm})$ to avoid DNA damage (Tomiyasu et al., 2014).

Another method to select CSCs is the use of molecular probes, termed aptamers, that are produced by the iterative in vitro selection process SELEX (Systematic Evolution of Ligands by EXponential enrichment) (Ellington and Szostak, 1990; Tuerk and Gold, 1990). Aptamers are short single-stranded oligonucleotides of DNA or RNA sequences that fold into unique secondary and tertiary structures that selectively bind the target proteins and other small molecules with high affinity and selectivity. They can be synthesized in vitro and therefore do not require animal or bacterial hosts for production. In recent years, in order to improve aptamers qualities and reducing time and cost of production, a number of new SELEX variants have been performed and among them, cell-SELEX uses whole living cells as target to select DNA aptamers (Shangguan et al., 2006; Sefah et al., 2010). Aptamers have many appealing features: low molecular weight, easy chemical modifications, low toxicity and immunogenicity, long shelf-life, high affinity ( $K_{d}$ value is in the picomolar to nanomolar range) and high specificity. They can be used in diagnosis, for purification processes, in drug discovery and in therapy (Proske et al., 2005). In particular, the therapeutic perspectives involve the targeting of chemotherapeutic agents, nanoparticles, drug-encapsulated liposomes and radioactive materials on cell specific biomarkers. Aptamers bind their targets with high affinity and specificity discriminating very closely related targets. The anti-theophylline aptamer is able to distinguish theophylline from caffeine, and the anti L-arginine RNA aptamer binds more strongly L-arginine than D-arginine (Jenison et al., 1994; Geiger et al., 1996). Aptamers are also useful in drug delivery strategy: 2'-fluoro- RNA aptamers have effect toward the highly expressed prostate specific membrane antigene (PSMA) (Lupold et al., 2002) and Docetaxel-encapsulated nanoparticles functionalized with a specific aptamer (A10) target PSMA expressing cells (Farokhzad et al., 2006). Another interesting example is AS1411 aptamer that recognizes Nucleolin (NCL), a multifactorial protein involved in many cellular pathways of cancer. AS1411 has been functionalized with cisplatin-liposome and evaluated in MCF-7 (NCL positive) and LNCaP (NCL negative) cell lines. The cytotoxic effects were higher in MCF-7 cells as compared to LNCaP cells (Cao et al., 2009). Moreover, specific aptamers are used in several assays to isolate, enrich and identify CSCs and for the characterization of specific markers for CSCs such as aptamers toward HA domain of CD4, RNA aptamers targeting CD133, a cell surface glycoprotein considered a universal marker of normal hematopoietic and organ-specific stem cells and aptamers identifying brain CSCs (Griguer et al., 2008; Kim et al., 2013).

\section{STRATEGIES TO ERADICATE CSCs}

CSCs are responsible for tumor re-growth and potentially resistant to antitumor therapies. Therefore, the development of

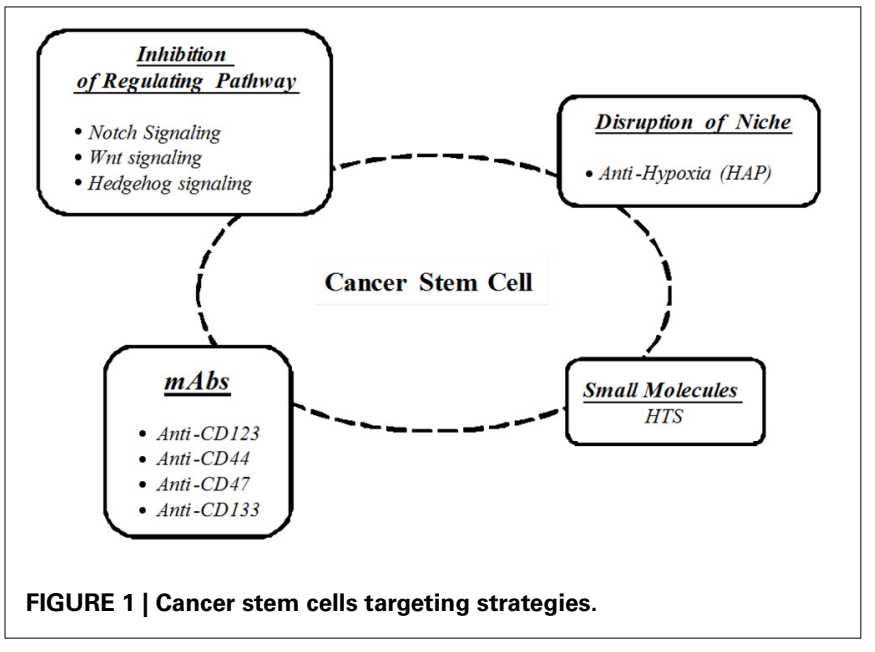

strategies that can act effectively against this subpopulation of cells has been envisaged, such as (Figure 1):

- Immunological therapies;

- Evaluation of genes and pathways pivotal in CSCs regulation;

- High-throughput screening (HTS) of potential inhibitory compounds;

- Regulation of tumor microenvironment.

\section{IMMUNOLOGICAL THERAPIES}

Since current cancer therapies fail to eradicate CSCs, causing cancer recurrence and progression, the use of monoclonal antibodies (mAbs) and antibody constructs selective for CSCs is a novel cancer therapeutic strategy. Several studies have been performed on cell surface markers that are associated with CSCs. These markers have been suggested as targets for antibodies, for antibody-drug conjugates (ADCs) in immunological therapies to overcome the side effects and the limitations of current cancer chemotherapies (Naujokat, 2014). Several mAbs, directed toward specific surface markers (Anti-CD123, Anti-CD44, Anti-CD47, Anti-CD133) or toward protein of CSCs (Anti-Notch1 and Anti-Frizzled) have been reported (Naujokat, 2014). Antibody constructs can be classified as bispecific antibodies (BsAb), targeting two different surface markers (such as BsAb-CD123 and -CD3) or as trispecific antibodies when they target three different markers (such as CD123, CD33, CD16) (Naujokat, 2014). The use of mAbs or mAbs constructs had high efficacy in tumor xenografts mice and in some clinical trials and since these markers or proteins are expressed in CSCs, they can be specifically targeted by mAbs or constructs without collateral tissue damage. Moreover, it is also possible to conjugate antineoplastic drugs to mAbs leading to ADCs. As example, Lou et al. have developed a dual-targeting drug delivery system displaying an outer layer of polymers and traditional anti-cancer drugs such as doxorubicin dispersed in the polymer (Lou et al., 2012). The internal part is represented by the ADCs since includes mAbs directed to the specific marker of CSCs (such as anti-CD133 mAb or anti-CD44 mAb), highly cytotoxic drugs (such as calicheamicin) and linkers. The inner ADCs can be released from the delivery system in tumor cells where CSCs are recognized by the specific mAb of the system and ADCs are 
endocytosed. Some ADCs have displayed good antitumor effects and have entered preclinical trials (Iyer and Kadambi, 2011).

PhotoChemical Internalization (PCI) is a another innovative drug delivery technology based on light-controlled cytosolic release of drugs entrapped in endosomes or lysosomes (Stratford et al., 2013).

The combination of CD133-targeting therapeutics with PCI technology, where light-activation is constrained to the tumor, has been performed to develop an immunotoxin consisting of a biotinylated anti-CD133 mAb bound to streptavidin-saporin system (Stratford et al., 2013). This combined strategy has been used in a sarcoma model system (harboring CSCs within the CD133 high population) and the results have demonstrated that PCI-based drug delivery by the CD133-receptor inhibited cells viability and growth, and the ability to form tumors in vivo. Since CD133 overexpression is also found in different tumors, the study performed on sarcoma model can be transferable to treatment of all solid tumors expressing CD133 (Smith et al., 2008; Waldron et al., 2011; Bostad et al., 2013).

\section{REGULATING PATHWAYS}

The inhibition of biological pathways crucial in the regulation of the renew and the maintenance of CSCs, in combination with traditional chemotherapies, is a promising strategy for the treatment of CSCs and to circumvent MDR.

\section{Notch pathway}

The Notch pathway is important in gene regulation and in cell differentiation processes. This pathway is involved in the pathogenesis of several human tumors such as ovarian cancer (Park et al., 2006). There are four members of the mammalian Notch receptor family (Notch 1-4) activated through a series of cleavage events. The mature Notch receptors are composed of two subunits generated from an initial cleavage event by furin-like convertase. Blaumueller et al. (1997) Notch signaling pathway activation occurs when a Notch receptor binds to ligands. This binding causes a receptor conformational change allowing a second cleavage by tumor necrosis-factor-alpha converting enzyme (TACE) (Brou et al., 2000). The following cleavage is carried out by preselenin (a $\gamma$-secretase) releasing Notch intracellular domain and activating target genes expression. Notch plays a significant role in ovarian CSCs regulation and in platinum resistance (Park et al., 2006; Takebe et al., 2011). Also, Notch 3 inhibitors increase the sensitivity of ovarian cancer to cisplatin, reducing the ovarian CSC population (McAuliffe et al., 2012).

\section{Wnt pathway}

The Wnt signaling pathway, regulating several processes fundamental in embryogenesis such as proliferation, differentiation, polarity, adhesion and motility, plays key roles in tumorigenesis. Indeed, the progression of several cancers is associated with specific mutations in Wnt pathway components resulting in dysregulated $\beta$-catenin-mediated gene transcription. There are two distinct pathways for transduction of Wnt signals: the "canonical" Wnt/ $\beta$-catenin pathway and the "non-canonical" $\beta$ catenin-independent pathway (Clevers and Nusse, 2012). The "canonical" pathway is activated by several Wnt ligands through the binding to Frizzled (FZD) receptors and to low-density lipoprotein receptor-related proteins-5/6 (LRP5/6) co-receptors. As a result, $\beta$-catenin accumulates in the cytoplasm, translocates to the nucleus and regulates transcription of $\mathrm{Wnt} / \beta$-catenin target genes by binding to the T-cell factor/lymphoid enhancer factor (TCF/LEF) (MacDonald et al., 2009). In the absence of Wnt signaling, $\beta$-catenin levels are regulated by a cytoplasmic destruction complex (DC). DC is a multiproteins complex composed of protein Axin, the tumor suppressor adenomatous polyposis coli protein (APC), casein kinase $\alpha(\mathrm{CK} 1 \alpha)$, glycogen synthase kinase $3 \beta$ (GSK3) and additional associated proteins such as the members of the PARP-family of poly-ADP-ribosylation enzymes (Tankyrases, TNKSs). Axin, the concentration-limiting component of DC, is pivotal for the stability of the $\beta$-catenin-DC. By destabilizing Axin, TNKSs directly control the levels of this protein. Therefore, TNKSs inhibition, promoting Axin stabilization, leads to $\beta$-catenin phosphorylation and degradation, attenuating Wnt signaling (Liu et al., 2002; Lee et al., 2003). For this reason, in recent years, considerable efforts have been made to identify drugs that inhibit Wnt/ $\beta$-catenin signaling. Another factor exerting a fundamental role in the biogenesis of Wnt pathway is represented by a member of the Membrane-Bound O-Acyl Transferase (MBOAT) family, Porcupine (PORCN) (Tanaka et al., 2000). PORCN is an integral membrane enzyme resident in the endoplasmic reticulum, required for the lipid modification of Wnt proteins. Acylation by PORCN is essential for the proper secretion and activity of Wnt signaling and, therefore, its inhibition is an attractive therapeutic strategy in diseases with increased Wnt signaling (Chen et al., 2009).

\section{Hedgehog pathway}

The Hh pathway is involved in several developmental processes of cells: determination of cell fate, patterning, proliferation, survival, and differentiation (Varjosalo and Taipale, 2008). In mammals, three Hh proteins (Sonic Hh, Indian $\mathrm{Hh}$, and Desert $\mathrm{Hh}$ ) are derived from proteolysis of inactive precursor that contains its own autoprocessing domain. Hh acts by binding to 12 transmembrane glycoprotein components Patched (Ptch). In the absence of ligand, Ptch constitutively represses the activity of Smoothened (Smo), a 7-pass transmembrane spanning protein with homology to G-protein coupled receptors. When Hh ligand binds to Ptch, the repression of Smo is released and the expression and/or post-translational processing of the three GLI zinc-finger transcription factors, inducing the expression of several target genes, is modulated (Sasaki et al., 1999). Overactivation of Hh pathway is associated with cancer and emerging data from many human tumors, including glioblastoma, breast cancer, pancreatic cancer, and chronic myeloid leukemia (CML), have suggested that Hh signaling regulates CSCs (Liu et al., 2006; Bar et al., 2007; Feldmann et al., 2007; Zhao et al., 2009). The Hh signaling pathway interacts also with other pathways commonly activated in human cancers, such as the phosphatidylinositol-3-kinase (PI3K)/Akt pathway (Riobo et al., 2006).

\section{PI3K/AKT pathway}

PI3K/AKT is important for pluripotency maintenance of stem cells. PI3K enzymes are normally regulated by growth factors 
and are useful to phosphorylate phospholipids on the plasma membrane (Hennessy et al., 2005). In addition, it has been suggested that PI3K/Akt activation pathway is required for CSCs maintenance and viability in breast cancer, prostate cancer, and brain tumor (Zhou et al., 2007; Hambardzumyan et al., 2008; Dubrovska et al., 2009). The PI3K/Akt pathway can also modulate functions of $\mathrm{ABC}$ transporters through various mechanisms. Inhibition of the PI3K/Akt pathway causes BCRP internalization in hematopoietic stem cells and glioma stem-like cells. Hence, the PI3K/Akt pathway can be an attractive target for cancer therapy (Mogi et al., 2003; Bleau et al., 2009).

\section{HIGH-THROUGHPUT SCREENING (HTS)}

The development of agents active toward CSCs population may be useful in the treatment of patients with recurrent cancer. HTS allows to identify potential compounds targeting specifically CSCs. In recent years, several studies have been carried out and in one of these studies the chemical library Microsource Spectrum collection of 2000 compounds has been screened to identify therapeutic agents inhibiting Glioblastome Multiforme stem cells (GSCs). This library has been selected based on the structural and biological diversity and consisted of FDA approved drugs, compounds in the late-phase clinical trials, experimental drugs and natural products. Among these, Disulfiram, a clinically approved drug for the treatment of alcoholism, was identified as a potent inhibitor of multiple patient-derived GSCs (Germain et al., 2013).

Another study has been carried out in order to identify agents able to selectively inhibit a cell-line model of breast CSCs screening over 300,000 compounds of the Molecular Libraries Small Molecules Repository (MLSMR) from the National Institute of Health (NIH). Among these compounds, a cinnamide analog displayed 20-fold selective inhibition of the breast CSC-line cell (HMLE_sh_Ecad) over the control (HMLE_sh_eGFP) (Hothi et al., 2012).

In another study, HTS of 825 potential drugs (the National Cancer Institute's "Mechanistic Set" library) toward ovarian CSCs and the subsequent identification of compounds displaying potential activity as ovarian CSC therapeutic agents is reported. Several compounds were classified as inhibitors and, among these, 5 compounds FDA-approved (dactinomycin, plicamycin, vinblastine, vincristine, and mepacrine) were identified as anticancer drugs (Mezencev et al., 2012).

\section{TUMOR MICROENVIRONMENT}

It has been proposed that CSCs are maintained by their surrounding microenvironment called "niche." Niche, important for CSCs sustaining, is composed by immune and stromal cells, blood vessels and extracellular matrix components. Biological processes, such as inflammation, hypoxia and angiogenesis, are important for CSCs, and signaling from this microenvironment is crucial for the activation of pathways involved in the maintenance of TICs functions (Cabarcas et al., 2011; Hanahan and Weinberg, 2011). Tumor hypoxia is implicated in the development of resistance to many conventional chemotherapeutic agents. It induces a decreased sensitivity to apoptotic and other cell-death signals, and increased signaling promoting angiogenesis, proliferation

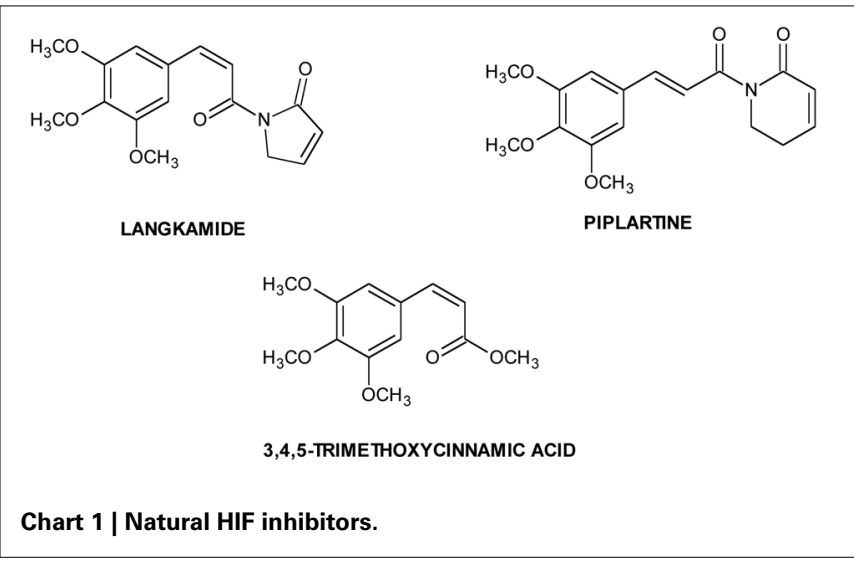

and systemic metastasis capacity (Feldmann, 2001; Kunz and Ibrahim, 2003). The initial response of cancer cells to hypoxia is the activation of hypoxia responsive transcription factors (HIFs) that regulate a number of genes involved in glucose metabolism, cell survival, erythropoiesis, stem cell maintenance, angiogenesis and resistance to chemotherapy and radiotherapy (Majmundar et al., 2010). Molecules like langkamide, piplartine and 3,4,5trimethoxycinnamic acid (Chart 1), displaying HIF-2 inhibitory activity, may be used for targeting HIFs mediated regulation of CSCs (Bokesch et al., 2011). Another important transcription factor, involved in tumor growth, progression, and in the resistance to chemotherapy, is NFkB: this factor and HIF1 $\alpha$ together regulate transcription of thousand genes controlling vital cellular processes (Gupta et al., 2010).

\section{MOLECULES ACTIVE TOWARD CSCs PORCUPINE AND TANKSs INHIBITORS}

In the last years, considerable efforts have been made to identify drugs able to inhibit $\mathrm{Wnt} / \beta$-catenin signaling, either by blocking Wnt secretion (PORCN inhibitors) or by interfering with $\beta$-catenin, by binding its transcription factor targets (TANKSs inhibitors).

Starting from four IWP ligands, additional PORCN inhibitors have been identified, that are characterized by two structural motifs of IWPs (phthalazinone and pyrimidinone moieties) interacting with PORCN and important for the activity. The lead optimization step led to a significant improvement in activity and to the identification of IWP-L6 (Chart 2) as a new sub-nanomolar PORCN inhibitor (Chen et al., 2009; Wang et al., 2013b). The first TANKSs inhibitor, identified by Huang et al. through a chemical genetic screen, was XAV-939 (Chart 2) (Huang et al., 2009b). It selectively affects $\beta$-catenin-mediated transcription, by stimulating its degradation by stabilizing Axin. By HTS, JW55, IWR-1, and WIKI4 (Chart 2) as specific tankyrases inhibitors have been discovered (Chen et al., 2009; James et al., 2012; Waaler et al., 2012).

\section{HAP: HYPOXIA-ACTIVATED BIOREDUCTIVE PRODRUGS}

The hypoxic microenvironment of solid tumors has attracted significant attention as target for the development of novel therapeutics for cancer treatment. A new class of drugs, the 


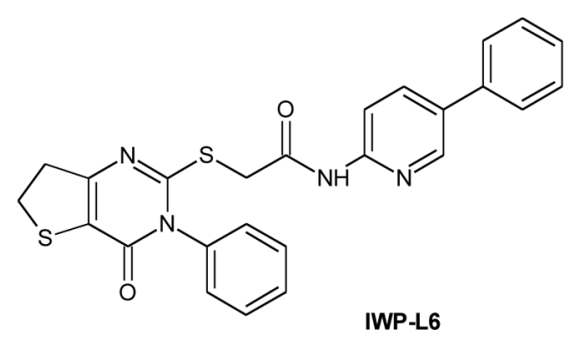<smiles>OC1=NC(c2ccc(C(F)(F)F)cc2)=NC2CCSCC12</smiles>

XAW939<smiles>CCCCCN1C(=O)C2C=CCc3cccc(c32)C(=O)N1CCCSc1nnc(-c2ccncc2)n1-c1ccc(OC)cc1</smiles>

Chart 2 | Porcupine and Tankyrase inhibitors.

hypoxia activated prodrugs (HAP), has been designed for selective activation under low oxygen conditions, typical of many solid tumors. These are prodrugs that are enzymatically converted into active metabolites (effectors) by endogenous enzymes under the hypoxic conditions that prevail in tumors (Rauth et al., 1998). Taking into account the different activation profile, HAP could be classified into two groups: (1) Class I HAP (such as benzotriazine $N$-oxides tirapazamine and SN30000), activated under relatively mild hypoxia; (2) Class II HAP (such as the nitro compounds PR-104A or TH-302), activated only under extreme hypoxia (Yin et al., 2012; Foehrenbacher et al., 2013). Several hypoxia-specific prodrugs are in various stages of clinical development, although no registered agents have been used in clinical therapy. Moreover, the bioreductive compounds are classified in five classes: (1) aromatic $N$-oxides; (2) aliphatic $N$-oxides; (3) nitro(hetero)cyclic compounds; (4) quinones; (5) metal complexes.

The N-oxide tirapazamine (TPZ, SR4233) (Chart 3 ) has been the most extensively evaluated compound in the clinic to date. TPZ exhibited up to 300-fold higher toxicity under anoxic conditions than aerobic conditions in vitro (Zeman et al., 1986). TPZ undergoes one-electron reduction to generate the corresponding radical able to produce DNA breaks and lesions (Shinde et al., 2010). Although TPZ has been evaluated in a number of phase II clinical trials (Marcu and Olver, 2006), the results have not been translated into increased efficacy over conventional treatment in phase III clinical trials (Rischin et al., 2010). SN30000 (Chart 3) is a TPZ analog with improved pharmacokinetic properties and is presently scheduled to enter phase I clinical trials (Hicks et al., 2010).

$N$-oxide banoxantrone (AQ4N) (Chart 3) is metabolized under hypoxia giving a high affinity DNA intercalating agent, AQ4, that inhibits topoisomerase II (Patterson et al., 1994). In preclinical studies, AQ4N, combined with radio- or chemotherapy, demonstrated significant increasing activity (Patterson et al., 2000).
PR-104 (Chart 3), currently in phase II clinical trials, is a water-soluble phosphate ester pre-prodrug that rapidly is hydrolyzed in vivo to the prodrug PR-104A, a dinitrobenzamide mustard that is reduced to $p$-hydroxylamine and $p$ amine metabolites by various oxidoreductases (Singleton et al., 2009). Another promising compound, TH-302 (Chart 3), is a 2-nitroimidazole-based nitrogen mustard prodrug. The reduction in hypoxic cells to 2-nitroimidazole and the subsequent bromoisophosphoramide mustard affects DNA repair pathways (Meng et al., 2012). TH-302, in combination with chemotherapy, is currently in phase II and III clinical trials.

Quinone compounds (porfiromycin, RH1, and apaziquone EO9) (Chart 3) show greater selectivity toward hypoxic cells where their activation under hypoxia is carried out by oneelectron reductases (Saunders et al., 2000; Phillips et al., 2013; Guise et al., 2014). Finally, although metal complexes could be potentially used as hypoxia-selective agents, none have been developed for clinical use so far.

\section{MISCELLANEOUS}

Several molecules, with unrelated chemical structures, are active toward CSCs. Among these, the antihelmintic niclosamide (Chart 4) selectively targets ovarian CSCs, and its effect is associated with the inhibition of metabolic pathways related to redox regulation (Yo et al., 2012). Metformin (Chart 4), an antidiabetic drug, selectively targets CSCs in multiple types of cancer including prostate, lung and breast (Hirsch et al., 2009; Shank et al., 2012) and, in combination with chemotherapeutic agents (such as doxorubicin, paclitaxel, and carboplatinum) inhibits tumor growth (Gotlieb et al., 2008). This drug also displays an anti-proliferative and pro-apoptotic effects on ovarian CSCs in vitro (Yasmeen et al., 2011). Retinoids, in co-administration with cis-platinum, affect ovarian CSCs, whereas carboplatinum alone is not active (Whitworth et al., 2012). Ericalyxin B, a diterpenoid isolated from Isodon eriocalyx displaying antitumor 
<smiles>Cc1n[n+]([O-])c2ccccc2[n+]1[O-]</smiles>

TPZ<smiles>C[N+](C)([O-])CCCC1=CC=C(NCC[N+](C)(C)[O-])C2C(=O)c3c(O)ccc(O)c3C(=O)C12</smiles><smiles>Cn1c(COP(=O)(NCCBr)NCCBr)cnc1[N+](=O)[O-]</smiles><smiles>O=S(=O)([O-])OCCCc1n[n+]([O-])c2cc3c(cc2[n+]1[O-])CCC3</smiles>

SN30000<smiles>CO[R5](=O)OCCN(CCBr)c1c(C(=O)NCCO[Po])cc([N+](=O)[O-])cc1[N+](=O)[O-]</smiles>

PR104<smiles>CCOC(=O)OCCO</smiles>

Chart 3 | Hypoxia Activated Prodrugs (HAP).

effects via multiple pathways, and 3-Bromopiruvate target ovarian CSCs inducing cell death (Leizer et al., 2011; Wintzell et al., 2012). Dactinomycin and Plicamycin, two FDA-approved CSCsinhibitory compounds, are used in the treatment of several cancers including gestational trophoblastic neoplasia, Wilms' tumor, testicular cancer and hypercalcemia associated with advanced malignancy (Kennedy, 1970; Perlia et al., 1970; Lewis et al., 1972; Frei, 1974; Fraschini et al., 2005; Lee et al., 2006). Disulfiram (Chart 4), used in alcoholism treatment, is able to reduce cell growth and self-renewal of glioblastoma stem cells resistant to temozolomide in vitro by activating apoptotic pathways that modulate Bcl-2 family (Liu et al., 2012). DECA-14 (Chart 4), an analog of dequalinium (DECA-10), an antimicrobial agent and Rapamycin were identified as neuroblastoma (NB) TICselective agents. Both compounds induce CSCs death in vitro, reduce NB xenograft tumor weight in vivo and decrease selfrenewal in treated tumors (Smith et al., 2010). Furthermore, NV-128 (Chart 4), an isoflavone derivative, induces cell death in chemoresistant CSCs population by inhibiting mitochondrial function and activating cell death pathways (Alvero et al., 2011).

\section{CSC AND MDR: REPOSITIONING STRATEGY}

The failure of cancer therapy is often due to tumor recurrence after chemotherapy because in several cancers a residual pool of CSCs remains (Dean et al., 2005). TICs that survive after therapy evolve in a population of chemoresistant cells able to sustain the growth of a more aggressive tumor. Among all the protective mechanisms for CSCs, $\mathrm{ABC}$ proteins overexpression is one of the mostly reported (An and Ongkeko, 2009; Calcagno et al., 2010; Fuchs et al., 2010; Clevers, 2011; Moitra et al., 2011; Pietras, 2011). There are two models useful to explain the connection between MDR and CSCs: (i) the original MDR model and (ii) the acquired MDR model (Holohan et al., 2013). The first model proposes that, after exposure to the chemotherapeutic agent, only CSCs expressing ABC transporters repopulate the tumor. The second suggests that, after chemotherapy, only CSCs survive and this population of survival cells, after mutations, originates new and more aggressive drug-resistant cell phenotypes (Holohan et al., 2013). The combination of CSCs targeting agents with novel or conventional cytotoxic drugs could lead to a potentiated effect. Flavonoids, a large family of polyphenolic molecules, modulate MDR transporters and inhibit CSCs growth (Colabufo et al., 


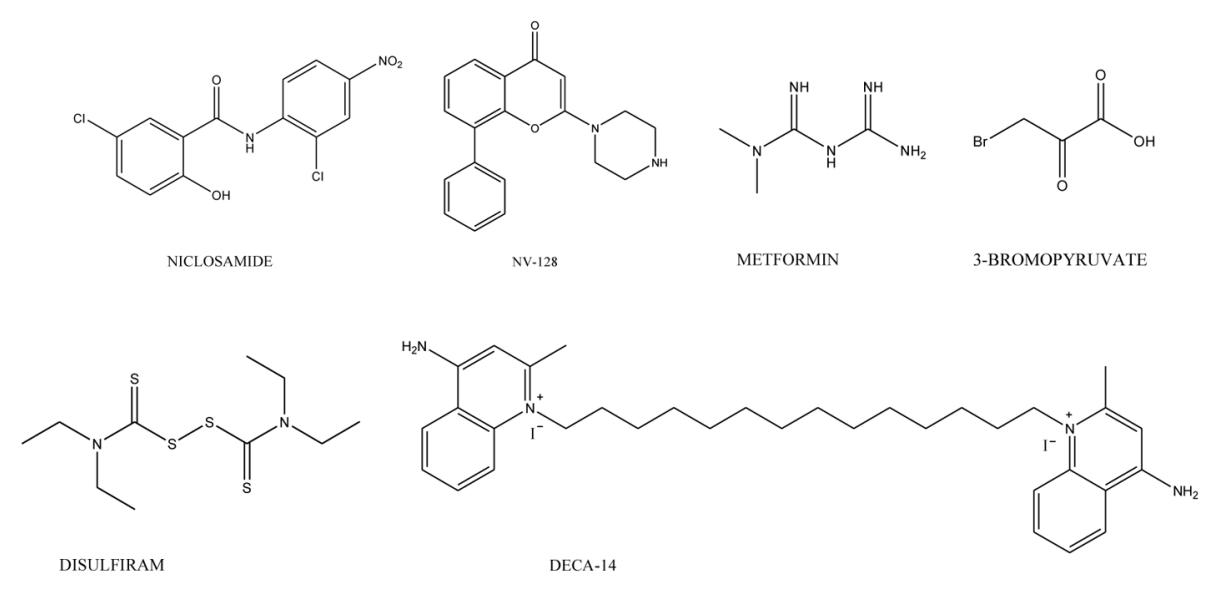

Chart 4 | Agents targeting CSCs.

2008c). Flavonoids anticancer properties are due to their antimitotic activity and to the inhibition of several enzymes. Recently, it has been suggested that flavonoids inhibit the function of ABC transporters such as P-gp, MRPs, and BCRP. Structural requirements for the interaction with these pumps are hydrophobic character and planarity. Flavonoids show low toxicity but, in the meantime, display a broad spectrum of biological activities (Colabufo et al., 2008c). Moreover, several studies have pointed out that flavonoids are able to affect CSCs. Luteolin, Casticin and 8-Bromo-7-methoxychrysin (BrMC) are active on glioma stem-like cells (Feng et al., 2012). BrMC is active on hepatocellular carcinoma (Hep-G2 cell line) where it induces apoptotic cell death by involving ROS products (Yang et al., 2010). LY294002, a PI3K specific inhibitor, blocks osteosarcoma CSCs cell cycle (G0/G1) in a dose-dependent manner inducing apoptosis by preventing phosphorylation of $\mathrm{PKB} / \mathrm{Akt}$ via $\mathrm{PI} 3 \mathrm{~K}$ phosphorylation inhibition. Several studies show that this compound also inhibits BCRP, P-gp, and MRP1 highly expressed in stem cells. LY294002 reverses MDR in CSCs overexpressing BCRP by internalizing this pump (Imai et al., 2012). LY294002 competitively inhibits MRP1mediated doxorubicin efflux in drug-resistant HT29RDB colon carcinoma cells. Sensitization was not restricted to doxorubicin, but it was also observed in cells treated with cisplatin, topotecan, and mitoxantron (Abdul-Ghani et al., 2006). Moreoever, LY294002 antagonizes transport activity of P-gp by reducing the degree of vincristine resistance in L1210/VCR mouse leukemic cell lines in a concentration-dependent manner (Barancík et al., 2006). However, the simultaneous inhibition of several cellular signaling pathways, transporters and channels may cause severe side effects.

Salinomycin, a polyether ionophore antibiotic isolated from Streptomyces albus, is able to affect CSCs in gastric cancer, lung adenocarcinoma, osteosarcoma, colorectal cancer, squamous cell carcinoma (SCC) and prostate by interfering with ABC transporters and CSC crucial pathways (Dong et al., 2011). The combination of salinomycin and the antibody for the anti-human epidermal growth factor receptor 2 (anti-HER2), trastuzumab, was found more efficacious than trastuzumab single-treatment in
MCF-7-derived breast CSCs and HER2-expressing breast cancer cells. In colorectal cancer and in SCC, salinomycin, but not oxaliplatin or cisplatin, is able to reduce the portion of CSCs (Basu et al., 2011; Dong et al., 2011; Tang et al., 2011; Wang, 2011; Zhi et al., 2011; Ketola et al., 2012; Oak et al., 2012). Moreover, salinomycin is active toward human AML CSCs, because it overcomes ABC transporter-mediated MDR and apoptosis resistance and inhibits P-gp/MDR1 in different cancer cells (Fuchs et al., 2010; Riccioni et al., 2010).

\section{CONCLUSIONS AND PERSPECTIVES}

Although several items about CSCs theory remain open, there is a large evidence demonstrating that CSCs are essential to initiate and maintain tumors. CSCs are involved in tumor re-growth and are resistant to conventional anti-cancer therapy because of several mechanisms. Among them, the overexpression of ABC transporters in CSCs membranes represents a novel target for eradicating tumor relapse. To date, several strategies have been employed to isolate, target CSCs and circumvent MDR: (i) the development of sensitive biomarkers and targeted-aptamers; (ii) the evaluation of CSCs microenvironment; (iii) the study of the genes and pathways involved in CSCs regulation; (iv) evaluation of known and new molecules able to affect both TIC populations and $\mathrm{ABC}$ transporters. Therefore, the next challenge in this field may be a multimodal strategy, an approach in which specific CSCs targeting drugs exert simultaneously the ability to circumvent tumor drug resistance (ABC transporters modulation) and cytotoxic activity toward CSCs and the corresponding differentiated tumor cells. The efficacy of this suggested multimodal strategy will be probed by using several scaffolds active toward MDR pumps on CSCs isolated by tumor specimens.

\section{REFERENCES}

Abdul-Ghani, R., Serra, V., Györffy, B., Jürchott, K., Solf, A., and Schäfer, R. (2006). The PI3K inhibitor LY294002 blocks drug export from resistant colon carcinoma cells overexpressing MRP1. Oncogene 25, 1743-1752. doi: 10.1038/sj.onc.1209201

Al-Hajj, M., Wicha, M. S., Benito-Hernandez, A., Morrison, S. J., and Clarke, M. F. (2003). Prospective identification of tumorigenic breast cancer 
cells. Proc. Natl. Acad. Sci. U.S.A. 100, 3983-3988. doi: 10.1073/pnas.0530 291100

Alvero, A. B., Montagna, M. K., Holmberg, J. C., Craveiro, V., Brown, D., and Mor, G. (2011). Targeting the mitochondria activates two independent cell death pathways in ovarian cancer stem cells. Mol. Cancer Ther. 10, 1385-1393. doi: 10.1158/1535-7163.MCT-11-0023

An, Y., and Ongkeko, W. M. (2009). ABCG2: the key to chemoresistance in cancer stem cells? Expert Opin. Drug Metab. Toxicol. 5, 1529-1542. doi: $10.1517 / 17425250903228834$

Baccelli, I., and Trumpp, A. (2012). The evolving concept of cancer and metastasis stem cells. J. Cell Biol. 198, 281-293. doi: 10.1083/jcb.201202014

Bar, E. E., Chaudhry, A., Lin, A., Fan, X., Schreck, K., Matsui, W., et al. (2007). Cyclopamine-mediated Hedgehog pathway inhibition depletes stem-like cancer cells in glioblastoma. Stem Cells 25, 2524-2533. doi: 10.1634/stemcells.20070166

Barancík, M., Bohácová, V., Sedlák, J., Sulová, Z., and Breier, A. (2006). LY294,002, a specific inhibitor of PI3K/Akt kinase pathway, antagonizes Pglycoprotein mediated multidrug resistance. Eur. J. Pharm. Sci. 29, 426-434. doi: 10.1016/j.ejps.2006.08.006

Basu, D., Montone, K. T., Wang, L. P., Gimotty, P. A., Hammond, R., Diehl, J. A., et al. (2011). Detecting and targeting mesenchymal-like subpopulations within squamous cell carcinomas. Cell Cycle 10, 12008-12016. doi: 10.4161/cc.10.12. 15883

Blaumueller, C. M., Qi, H., Zagouras, P., and Artavanis-Tsakonas, S. (1997). Intracellular cleavage of Notch leads to a heterodimic receptor on plasma membrane. Cell 90, 281-291. doi: 10.1016/S0092-8674(00)80336-0

Bleau, A. M., Hambardzumyan, D., Ozawa, T., Fomchenko, E. I., Huse, J. T., Brennan, C. W., et al. (2009). PTEN/PI3K/Akt pathway regulates the side population phenotype and ABCG2 activity in glioma tumor stem-like cell. Cell Stem Cell 4, 226-235. doi: 10.1016/j.stem.2009.01.007

Bokesch, H. R., Gardella, R. S., Rabe, D. C., Bottaro, D. P., Linehan, W. M., McMahon, J. B., et al. (2011). A new hypoxia inducible factor-2 inhibitory pyrrolinone alkaloid from roots and stems of Piper sarmentosum. Chem. Pharm. Bull. 59, 1178-1179. doi: 10.1248/cpb.59.1178

Boman, B. M., and Wicha, M. S. (2008). Cancer stem cells: a step toward the cure. J. Clin. Oncol. 26, 2795-2799. doi: 10.1200/JCO.2008.17.7436

Bostad, M., Berg, K., Høgset, A., Skarpen, E., Stenmark, H., and Selbo, P. K. (2013). Photochemical internalization (PCI) of immunotoxins targeting CD133 is specific and highly potent at femtomolar levels in cells with cancer stemcell properties. J. Control. Release 168, 317-326. doi: 10.1016/j.jconrel.2013. 03.023

Brou, C., Loget, F., Gupta, N., Bessia, C., LeBail, O., Doedens, J. R., et al. (2000). A novel proteolytic cleavage involved in Notch signaling: the role of the disintegrin-metalloprotease TACE. Mol. Cell 5, 207-216. doi: 10.1016/S10972765(00)80417-7

Cabarcas, S. M., Mathews, L. A., and Farrar, W. L. (2011). The cancer stem cell niche-there goes the neighborhood? Int. J. Cancer 129, 2315-2327. doi: 10.1002/ijc. 26312

Calcagno, A. M., Salcido, C. D., Gillet, J. P., Wu, C. P., Fostel, J. M., Mumau, M. D., et al. (2010). Prolonged drug selection of breast cancer cells and enrichment of cancer stem cell characteristics. J. Natl. Cancer Inst. 102, 1637-1652. doi: 10.1093/jnci/djq361

Cao, Z., Tong, R., Mishra, A., Xu, W., Whong, G. C., Cheng, J., et al. (2009). Reversible cell-specific drug delivery with aptamer-funcionalized liposomes. Angew. Chem. Int. Ed. Engl. 48, 6494-6498. doi: 10.1002/anie.200901452

Carla, F., Kim, B., Jackson, E. L., Woolfenden, A. E., Lawrence, S., Babar, I., et al. (2005). Identification of bronchioalveolar stem cells in normal lung and lung cancer. Cell 121, 823-835. doi: 10.1016/j.cell.2005.03.032

Challen, G. A., and Little, M. H. (2006). A side order of stem cells: the SP phenotype. Stem Cells 24, 3-12. doi: 10.1634/stemcells.2005-0116

Charafe-Jauffret, E., Ginestier, C., Iovino, F., Tarpin, C., Diebel, M., Esterni, B., et al. (2010). Aldehyde dehydrogenase 1-positive cancer stem cells mediate metastasis and poor clinical outcome in inflammatory breast cancer. Clin. Cancer Res. 16, 45-55. doi: 10.1158/1078-0432.CCR-09-1630

Chen, B., Dodge, M. E., Tang, W., Lu, J., Ma, Z., Fan, C. W., et al. (2009). Small moleculemediated disruption of Wnt dependent signaling in tissue regeneration and cancer. Nat. Chem. Biol. 5, 100-107. doi: 10.1038/nchembio.137

Cheung, A. M., Wan, T. S., Leung, J. C., Chan, L. Y., Huang, H., Kwong, Y. L., et al. (2007). Aldehyde dehydrogenase activity in leukemic blasts defines a subgroup of acute myeloid leukemia with adverse prognosis and superior NOD/SCID engrafting potential. Leukemia 21, 1423-1430. doi: 10.1038/sj.leu.2404721

Clevers, H. (2011). The cancer stem cell: premises, promises and challenges. Nat. Med. 17, 313-319. doi: 10.1038/nm.2304

Clevers, H., and Nusse, R. (2012). Wnt/beta-catenin signaling and disease. Cell 149, 1192-1205. doi: 10.1016/j.cell.2012.05.012

Colabufo, N. A., Berardi, F., Cantore, M., Contino, M., Inglese, C., Niso, M., et al. (2010). Perspectives of P-glycoprotein modulating agents in oncology and neurodegenerative diseases: pharmaceutical, biological, and diagnostic potentials. J. Med. Chem. 53, 1883-1897. doi: 10.1021/jm900743c

Colabufo, N. A., Berardi, F., Cantore, M., Perrone, M. G., Contino, M., Inglese, C., et al. (2008a). Small P-gp modulating molecules: SAR studies on tetrahydroisoquinoline derivatives. Bioorg. Med. Chem. 16, 362-373. doi: 10.1016/j.bmc.2007.09.039

Colabufo, N. A., Berardi, F., Cantore, M., Perrone, M. G., Contino, M., Inglese, C., et al. (2008b). 4-Biphenyl and 2-naphthyl substituted 6,7dimethoxytetrahydroisoquinoline derivatives as potent P-gp modulators. Bioorg. Med. Chem. 16, 3732-3743. doi: 10.1016/j.bmc.2008.01.055

Colabufo, N. A., Berardi, F., Cantore, M., Perrone, M. G., Contino, M., Inglese, C., et al. (2009). Multi-drug-resistance-reverting agents: 2-aryloxazole and 2arylthiazole derivatives as potent BCRP or MRP1 inhibitors. ChemMedChem 4, 188-195. doi: 10.1002/cmdc.200800329

Colabufo, N. A., Berardi, F., Contino, M., Inglese, C., and Perrone, R. (2008c). Multidrug Resistance: Biological and Pharmaceutical Advance in the Antitumour Treatment. Kerala: Research Signpost.

Colabufo, N. A., Contino, M., Cantore, M., Capparelli, E., Perrone, M. G., Cassano, G., et al. (2013). Naphthalenyl derivatives for hitting P-gp/MRP1/BCRP transporters. Bioorg. Med. Chem. 21, 1322-1330. doi: 10.1016/j.bmc.2012.12.021

Coley, H. M. (2010). Overcoming multidrug resistance in cancer: clinical studies of p-glycoprotein inhibitors. Methods Mol. Biol. 596, 341-358. doi: 10.1007/978-160761-416-6_15

Contino, M., Cantore, M., Capparelli, E., Perrone, M. G., Niso, M., Inglese, C., et al. (2012). A benzopyrane derivative as P-glycoprotein stimulator: a potential agent to decrease $\beta$-amyloid accumulation in Alzheimer's disease. ChemMedChem 7 , 391-395. doi: 10.1002/cmdc.201100469

Contino, M., Zinzi, L., Cantore, M., Perrone, M. G., Leopoldo, M., Berardi, F., et al. (2013b). Activity-Lipophilicity relationship studies on P-gp ligands designed as simplified Tariquidar bulky fragments. Bioorg. Med. Chem. Lett. 23, 3728-3731. doi: 10.1016/j.bmcl.2013.05.019

Contino, M., Zinzi, L., Perrone, M. G., Leopoldo, M., Berardi, F., Perrone, R. et al. (2013a). Potent and selective tariquidar bioisosters as potential PET radiotracers for imaging P-gp. Bioorg. Med. Chem. Lett. 23, 1369-1373. doi: 10.1016/j.bmcl.2012.12.084

Dean, M., Fojo, T., and Bates, S. (2005). Tumour stem cells and drug resistance. Nat. Rev. Cancer 5, 275-284. doi: 10.1038/nrc1590

Dobbin, Z. C., and Landen, C. N. (2013). Isolation and characterization of potential cancer stem cells from solid human tumors-potential applications. Curr. Protoc. Pharmacol. 63, Unit 14.28. doi: 10.1002/0471141755.ph1428s63

Dong, T. T., Zhou, H. M., Wang, L. L., Feng, B., Lv, B., and Zheng, M. H. (2011). Salinomycin selectively targets'CD133+' cell subpopulations and decreases malignant traits in colorectal cancer lines. Ann. Surg. Oncol. 18, 6797-1804. doi: 10.1245/s10434-011-1561-2

Dubrovska, A., Kim, S., Salamone, R. J., Walker, J. R., Maira, S. M., GarcíaEcheverría, C., et al. (2009). The role of PTEN/Akt/PI3K signaling in the maintenance and viability of prostate cancer stem-like cell populations. Proc. Natl. Acad. Sci. U.S.A. 106, 268-273. doi: 10.1073/pnas.0810956106

Ellington, A. D., and Szostak, J. W. (1990). In vitro selection of RNA molecules that bind specific ligands. Nature 346, 818-822. doi: 10.1038/346818a0

Erba, E., Ubezio, P., Broggini, M., Ponti, M., and D'Incalci, M. (1988). DNA damage, cytotoxic effect and cell-cycle perturbation of Hoechst 33342 on L1210 cells in vitro. Cytometry 9, 1-6. doi: 10.1002/cyto.990090102

Fael Al-Mayhani, T. M., Ball, S. L., Zhao, J. W., Fawcett, J., Ichimura, K., Collins, P. V., et al. (2009). An efficient method for derivation and propagation of glioblastoma cell lines that conserves the molecular profile of their original tumours. J. Neurosci. Methods 176, 192-199. doi: 10.1016/j.jneumeth.2008. 07.022

Fang, D., Nguyen, T. K., Leishear, K., Finko, R., Kulp, A. N., Hotz, S., et al. (2005). A tumorigenic subpopulation with stem cell properties in melanomas. Cancer Res. 65, 9328-9337. doi: 10.1158/0008-5472.CAN-05-1343 
Farokhzad, O. C., Cheng, J., Teply, B. A., Sherifi, I., Jon, S., Kantoff, P. W., et al. (2006). Targeted nanoparticle-aptamer bioconjugates for cancer chemotherapy in vivo. Proc. Natl. Acad. Sci. U.S.A. 103, 6315-6320. doi: 10.1073/pnas. 0601755103

Feldmann, G., Dhara, S., Fendrich, V., Bedja, D., Beaty, R., Mullendore, M., et al. (2007). Blockade of hedgehog signaling inhibits pancreatic cancer invasion and metastases: a new paradigm for combination therapy in solid cancers. Cancer Res. 67, 2187-2196. doi: 10.1158/0008-5472.CAN-06-3281

Feldmann, H. J. (2001). Oxygenation of human tumors-implications for combined therapy. Lung Cancer 33, S77-S83. doi: 10.1016/S0169-5002(01)00306-3

Feng, X., Zhou, Q., Liu, C., and Tao, M. (2012). Drug screening study using glioma stem-like cells. Mol. Med. Rep. 6, 1117-1120. doi: 10.3892/mmr.2012.1040

Foehrenbacher, A., Patel, K., Abbattista, M., Guise, C. P., Secomb, T. W., Wilson, W. R., et al. (2013). The role of by stander effects in the antitumor activity of the hypoxia-activated prodrug PR-104. Front. Oncol. 3:263. doi: $10.3389 /$ fonc. 2013.00263

Fraschini, A., Bottone, M. G., Scovassi, A. I., Denegri, M., Risueño, M. C., Testillano, P. S., et al. (2005). Changes in extranucleolar transcription during actinomycin D-induced apoptosis. Histol. Histopathol. 20, 107-117.

Frei, E. 3rd. (1974). The clinical use of actinomycin. Cancer Chemother. Rep. 58, 49-54.

Fuchs, D., Daniel, V., Sadeghi, M., Opelz, G., and Naujokat, C. (2010). Salinomycin overcomes $\mathrm{ABC}$ transporter-mediated multidrug and apoptosis resistance in human leukemia stem cell-like KG-1a cells. Biochem. Biophys. Res. Commun. 394, 1098-1104. doi: 10.1016/j.bbrc.2010.03.138

Gao, M. Q., Choi, Y. P., Kang, S., Youn, J. H., and Cho, N. H. (2010). CD24+ cells from hierarchically organized ovarian cancer are enriched in cancer stem cells. Oncogene 29, 2672-2680. doi: 10.1038/onc.2010.35

Geiger, A., Burgstaller, P., von der Eltz, H., Roeder, A., and Famulok, M. (1996). RNA aptamers that bind L-arginine with sub-micromolar dissociation constants and high enantioselectivity. Nucleic Acids Res. 24, 1029-1036. doi: 10.1093/nar/24.6.1029

Germain, A. R., Carmody, L. C., Nag, P. P., Morgan, B., VerPlank, L., Fernandez, C., et al. (2013). Cinnameds as selectiva small-molecule inhibitors of a cellular model of breast cancer stem cells. Bioorg. Med. Chem. Lett. 23, 1834-1838. doi: 10.1016/j.bmcl.2013.01.025

Gimenez-Bonafe, P., Guillen Canovas, A., Ambrosio, S., Tortosa, A., and PerezTomas, R. (2008). "Drugs modulating MDR," in Multidrug Resistance: Biological and Pharmaceutical Advance in the Antitumour Treatment, ed N. A. Colabufo (Kerala: Research Signpost), 63-99.

Goodell, M. A., Brose, K., Paradis, G., Conner, A. S., and Mulligan, R. C. (1996), Isolation and functional properties of murine hematopoietic stem cells that are replicating in vivo. J. Exp. Med. 183, 1797-1806. doi: 10.1084/jem.183. 4.1797

Gotlieb, W. H., Saumet, J., Beauchamp, M. C., Gu, J., Lau, S., Pollak, M. N., et al. (2008). In vitro metformin anti-neoplastic activity in epithelial ovarian cancer. Gynecol. Oncol. 110, 246-250. doi: 10.1016/j.ygyno.2008.04.008

Griguer, C. E., Oliva, C. R., Gobin, E., Marcorelles, P., Benos, D. J., Lancaster, J. R. Jr., et al. (2008). CD133 is a marker of bioenergetic stress in human glioma. PLoS ONE 3:e3655. doi: 10.1371/journal.pone.0003655

Guise, C. P., Mowday, A. M., Ashoorzadeh, A., Yuan, R., Lin, W. H., Wu, D. H., et al. (2014). Bioreductive prodrugs as cancer therapeutics: targeting tumor hypoxia. Chin. J. Cancer 33, 80-86. doi: 10.5732/cjc.012.10285

Gupta, S. C., Sundaram, C., Reuter, S., and Aggarwal, B. B. (2010). Inhibiting NFкB activation by small molecules as a therapeutic strategy. Biochim. Biophys. Acta 1799, 775-787. doi: 10.1016/j.bbagrm.2010.05.004

Hambardzumyan, D., Becher, O. J., Rosenblum, M. K., Pandolfi, P. P., ManovaTodorova, K., and Holland, E. C. (2008). PI3K pathway regulates survival of cancer stem cells residing in the perivascular niche following radiation in medulloblastoma in vivo. Genes Dev. 22, 436-448. doi: 10.1101/gad. 1627008

Hamburger, A. W., and Salmon, S. E. (1977). Primary bioassay of human tumor stem cells. Science 197, 461-463. doi: 10.1126/science.560061

Hanahan, D., and Weinberg, R. A. (2011). Hallmarks of cancer: the next generation. Cell 144, 646-674. doi: 10.1016/j.cell.2011.02.013

Hemmati, H. D., Nakano, I., Lazareff, J. A., Masterman-Smith, M., Geschwind, D. H., Bronner-Fraser, M., et al. (2003). Cancerous stem cells can arise from pediatric brain tumors. Proc. Natl. Acad. Sci. U.S.A. 100, 15178-15183. doi: $10.1073 /$ pnas. 2036535100
Hennessy, B. T., Smith, D. L., Ram, P. T., Lu, Y., and Mills, G. B. (2005). Exploiting the PI3K/AKT pathway for cancer drug discovery. Nat. Rev. Drug Discov. 4, 988-1004. doi: $10.1038 / \mathrm{nrd} 1902$

Hicks, K. O., Siim, B. G., Jaiswal, J. K., Pruijn, F. B., Fraser, A. M., Patel, R., et al. (2010). Pharmacokinetic/pharmacodynamic modeling identifies SN30000 and SN29751 as tirapazamine analogues with improved tissue penetration and hypoxic cell killing in tumors. Clin. Cancer Res. 16, 20946-20957. doi: 10.1158/ 1078-0432.CCR-10-1439

Hirsch, H. A., Iliopoulos, D., Tsichlis, P. N., and Struhl, K. (2009). Metformin selectively targets cancer stem cells, and acts togheter with chemotherapy in block tumor growth and prolong remission. Cancer Res. 69, 7507-7511. doi: 10.1158/0008-5472.CAN-09-2994

Hirschhaeuser, F., Menne, H., Dittfeld, C., West, J., Mueller-Klieser, W., and KunzSchughart, L. A. (2010). Multicellular tumor spheroids: an underestimated tool is catching up again. J. Biotechnol. 148, 3-15. doi: 10.1016/j.jbiotec.2010. 01.012

Holohan, C., Van Schaeybroeck, S., Longley, D. B., and Johnston, P. G. (2013). Cancer drug resistance: an evolving paradigm. Nat. Rev. Cancer 13, 714-726. doi: $10.1038 / \mathrm{nrc} 3599$

Hothi, P., Martins, T. J., Chen, L., Deleyrole, L., Yoon, J.-G., Reynolds, B., et al. (2012). High-throughput chemical screens identify Disulfiram as an inhibitor of human glioblastoma stem cells. Oncotarget 3, 1124-1136.

Huang, E. H., Hynes, M. J., Zhang, T., Ginestier, C., Dontu, G., Appelman, H., et al. (2009a). Aldehyde dehydrogenase 1 is a marker for normal and malignant human colonic stem cells (SC) and tracks SC overpopulation during colon tumorigenesis. Cancer Res. 69, 3382-3389. doi: 10.1158/0008-5472.CAN08-4418

Huang, S. M., Mishina, Y. M., Liu, S., Cheung, A., Stegmeier, F., Michaud, G. A., et al. (2009b). Tankyrase inhibition stabilizes axin and antagonizes Wnt signaling. Nature 461, 614-620. doi: 10.1038/nature08356

Imai, Y., Yamagishi, H., Ono, Y., and Ueda, Y. (2012). Versatile inhibitory effects of the flavonoid-derived PI3K/Akt inhibitor, LY294002, on ATP-binding cassette transporters that characterize stem cells. Clin. Transl. Med. 1, 24-28. doi: 10.1186/2001-1326-1-24

Iyer, U., and Kadambi, V. J. (2011). Antibody drug conjugates-Trojan horses in the war on cancer. J. Pharmacol. Toxicol. Methods 64, 207-212. doi: 10.1016/j.vascn. 2011.07.005

James, R. G., Davidson, K. C., Bosch, K. A., Biechele, T. L., Robin, N. C., Taylor, R. J., et al. (2012). WIKI4, a novel inhibitor of Tankyrase and Wnt/B-Catenin signaling. PLoS ONE 7:e50457. doi: 10.1371/journal.pone.0050457

Janikowa, M., and Skarda, J. (2012). Differentiation pathways in carcinogenesis and in chemo- and radioresistance. Neoplasma 59, 6-17. doi: 10.4149/neo_2012_002

Jenison, R. D., Gill, S. C., Pardi, A., and Polisky, B. (1994). High-resolution molecular discrimination by RNA. Science 263, 1425-1429. doi: 10.1126/science. 7510417

Jiang, F., Qiu, Q., Khanna, A., Todd, N. W., Deepak, J., Xing, L., et al. (2009). Aldehyde dehydrogenase 1 is a tumor stem cell-associated marker in lung cancer. Mol. Cancer Res. 7, 330-338. doi: 10.1158/1541-7786.MCR$08-0393$

Jiang, W., Peng, J., Zhang, Y., Cho, W. C., and Jin, K. (2012). The implications of cancer stem cells for cancer therapy. Int. J. Mol. Sci. 13, 16636-16657. doi: $10.3390 /$ ijms 131216636

Jin, L., Hope, J. K., Zhai, Q., Smadja-Joffe, F., and Dick, J. E. (2006). Targeting of CD44 eradicates human acute myeloid leukemic stem cells. Nat. Med. 12, 1167-1174. doi: $10.1038 / \mathrm{nm} 1483$

Kennedy, B. J. (1970). Mithramycin therapy in advanced testicular neoplasms. Cancer 26, 755-766. doi: 10.1002/1097-0142(197010)26:4<755::AIDCNCR2820260403 > 3.0.CO;2-U

Ketola, K., Hilvo, M., Hyotylainen, T., Vuoristo, A., Ruskeepää, A. L., Orešić, M., et al. (2012). Salinomycin inhibits prostate cancer growth and migration via induction of oxidative stress. Br. J. Cancer 106, 19-106. doi: 10.1038/bjc. 2011.530

Kim, Y., Wu, Q., Hamerlik, P., Hitomi, M., Sloan, A. E., Barnett, G. H., et al. (2013). Aptamer identification of brain tumor-initiating cells. Cancer Res. 73, 4923-4936. doi: 10.1158/0008-5472.CAN-12-4556

Kobune, M., Takimoto, R., Murase, K., Iyama, S., Sato, T., Kikuchi, S., et al. (2009). Drug resistance is dramatically restored by hedgehog inhibitors in CD34+ leukemic cells. Cancer Sci. 100, 948-955. doi: 10.1111/j.1349-7006.2009. 01111.x 
Kondo, T., Setoguchi, T., and Taga, T. (2004). Persistence of a small subpopulation of cancer stem-like cells in the C6 glioma cell line. Proc. Natl. Acad. Sci. U.S.A. 101, 781-786. doi: 10.1073/pnas.0307618100

Korkaya, H., Paulson, A., Charafe-Jauffret, E., Ginestier, C., Brown, M., Dutcher, J., et al. (2009). Regulation of mammary stem/progenitor cells by PTEN/Akt/ $\beta$ catenin signaling. PLoS Biol. 7:e1000121. doi: 10.1371/journal.pbio. 1000121

Kunz, M., and Ibrahim, S. M. (2003). Molecular responses to hypoxia in tumor cells. Mol. Cancer 2:23. doi: 10.1186/1476-4598-2-23

Kwon, M. J., and Shin, Y. K. (2013). Regulation of ovarian cancer stem cells or tumor-initiating cells. Int. J. Mol. Sci. 14, 6624-6648. doi: 10.3390/ijms140 46624

Landen, C. N. Jr., Goodman, B., Katre, A. A., Steg, A. D., Nick, A. M., Stone, R. L., et al. (2010). Targeting aldehyde dehydrogenase cancer stem cells in ovarian cancer. Mol. Cancer Ther. 9, 3186-3199. doi: 10.1158/1535-7163.MCT-10-0563

Lapidot, T., Sirard, C., Vormoor, J., Murdoch, B., Hoang, T., CaceresCortes, J., et al. (1994). A cell initiating human acute myeloid leukaemia after transplantation into SCID mice. Nature 367, 645-648. doi: 10.1038/ $367645 \mathrm{a} 0$

Lawson, D. A., Xin, L. I., Lukacs, R. U., Cheng, D., and Witte, O. N. (2007). Isolation and functional characterization of murine prostate stem cells. Proc. Natl. Acad. Sci. U.S.A. 104, 181-186. doi: 10.1073/pnas.0609684104

Lee, E., Salic, A., Kruger, R., Heinrich, R., and Kirschner, M. W. (2003). The roles of APC and Axin derived from experimental and theoretical analysis of the Wnt pathway. PLoS Biol. 1:E10. doi: 10.1371/journal.pbio.0000010

Lee, T. J., Jung, E. M., Lee, J. T., Kim, S., Park, J. W., Choi, K. S., et al. (2006). Mithramycin A sensitizes cancer cells to TRAIL-mediated apoptosis by downregulation of XIAP gene promoter through Spl sites. Mol. Cancer Ther. 5, 2737-2746. doi: 10.1158/1535-7163.MCT-06-0426

Leizer, A. L., Alvero, A. B., Fu, H. H., Holmberg, J. C., Cheng, Y. C., Silasi, D. A., et al. (2011). Regulation of inflammation by the NF-kappa B pathway in ovarian cancer stem cells. Am. J. Reprod. Immunol. 65, 438-447. doi: 10.1111/j.16000897.2010.00914.x

Lewis, J. L. Jr. (1972). Chemotherapy of gestational choriocarcinoma. Cancer 30, 1517-1521. doi: 10.1002/1097-0142(197212)30:6<1517::AIDCNCR2820300616>3.0.CO;2-8

Li, C., Heidt, D. G., Dalerba, P., Burant, C. F., Zhang, L., Adsay, V., et al. (2007). Identification of pancreatic cancer stem cells. Cancer Res. 67, 1030-1037. doi 10.1158/0008-5472.CAN-06-2030

Li, T., Su, Y., Mei, Y., Leng, Q., Leng, B., Liu, Z., et al. (2010). ALDH1A is a marker for malignant prostate stem cells and predictor of prostate cancer patients' outcome. Lab. Invest. 90, 234-244. doi: 10.1038/labinvest. 2009.127

Liu, C., Li, Y., Semenov, M., Han, C., Baeg, G. H., Tan, Y., et al. (2002). Control of beta-catenin phosphorylation/degradation by a dual-kinase mechanism. Cell 108, 837-847. doi: 10.1016/S0092-8674(02)00685-2

Liu, M., Sakamaki, T., Casimiro, M. C., Willmarth, N. E., Quong, A. A., Ju, X., et al. (2010). The canonical NF- $\kappa B$ pathway governs mammary tumorigenesis in transgenic mice and tumor stem cell expansion. Cancer Res. 70, 10464-10473. doi: 10.1158/0008-5472.CAN-10-0732

Liu, P., Brown, S., Goktug, T., Channathodiyil, P., Kannappan, V., Hugnot, J. P., et al. (2012). Cytotoxic effect of disulfiram/copper on human glioblastoma cell lines and ALDH positive cancer-stem-like cells. Br. J. Cancer 9, 1488-1497. doi: 10.1038/bjc. 2012.442

Liu, S., Dontu, G., Mantle, I. D., Patel, S., Ahn, N. S., Jackson, K. W., et al. (2006). Hedgehog signaling and Bmi-1 regulate self-renewal of normal and malignant human mammary stem cells. Cancer Res. 66, 6063-6071. doi: 10.1158/00085472.CAN-06-0054

Lorico, A., and Rappa, G. (2011). Phenotypic heterogeneity of breast cancer stem cells. J. Oncol. 2011:135039. doi: 10.1155/2011/135039

Lou, D., Wang, B., Wang, Y., and Cao, Y. (2012). Selective killing of cancer stem cells by a novel dual-targeting strategy. Med. Hypotheses 79, 430-432. doi: 10.1016/j.mehy.2012.06.012

Lupold, S. E., Hicke, B. J., Lin, Y., and Coffet, D. S. (2002). Identification and characterization of nuclease-stabilized RNA molecules that bind human prostate cancer cells via the prostate-specific membrane antigen. Cancer Res. 62, 4029-4033.

Ma, S., Lee, T. K., Zheng, B. J., Chan, K. W., and Guan, X. Y. (2008). CD133+ HCC cancer stem cells confer chemoresistance by preferential expression of the Akt/PKB survival pathway. Oncogene 27, 1749-1758. doi: 10.1038/si.onc. 1210811

MacDonald, B. T., Tamai, K., and He, X. (2009). Wnt/beta-catenin signaling: components, mechanisms, and diseases. Dev. Cell 17, 9-26. doi: 10.1016/j.devcel.2009.06.016

Majmundar, A. J., Wong, W. J., and Simon, M. C. (2010). Hypoxia-inducible factors and the response to hypoxic stress. Mol. Cell 40, 294-309. doi: 10.1016/j.molcel.2010.09.022

Marcu, L., and Olver, I. (2006). Tirapazamine: from bench to clinical trials. Curr. Clin. Pharmacol. 1, 71-79. doi: 10.2174/157488406775268192

McAuliffe, S. M., Morgan, S. L., Wyant, G. A., Tran, L. T., Muto, K. W., Chen, Y. S., et al. (2012). Targeting Notch, a key pathway for ovarian cancer stem cells, sensitizes tumors to platinum therapy. Proc. Natl. Acad. Sci. U.S.A. 109, E2939-E2948. doi: 10.1073/pnas.1206400109

Meng, F., Evans, J. W., Bhupathi, D., Banica, M., Lan, L., Lorente, G., et al. (2012). Molecular and cellular pharmacology of the hypoxia-activated prodrug TH-302. Mol. Cancer Ther. 11, 740-751. doi: 10.1158/1535-7163.MCT-11-0634

Mezencev, R., Wang, L., and McDonald, J. F. (2012). Identification of inhibitors of ovarian cancer stem-like cells by high-throughput screening. J. Ovarian Res. 5, 30-41. doi: 10.1186/1757-2215-5-30

Mogi, M., Yang, J., Lambert, J. F., Colvin, G. A., Shiojima, I., Skurk, C., et al. (2003). Akt signaling regulates side population cell phenotype via Bcrp translocation. J. Biol. Chem. 278, 39068-39075. doi: 10.1074/jbc.M306362200

Moitra, K., Lou, H., and Dean, M. (2011). Multidrug efflux pumps and cancer stem cells: insights into multidrug resistance and therapeutic development. Clin Pharmacol. Ther. 89, 491-502. doi: 10.1038/clpt.2011.14

Moreb, J. S. (2008). Aldehyde dehydrogenase as a marker for stem cells. Curr. Stem Cell Res. Ther. 3, 237-246. doi: 10.2174/157488808786734006

Naujokat, C. (2014). Monoclonal antibodies against human cancer stem cells. Immunotherapy 6, 290-308. doi: 10.2217/imt.14.4

Nesi, G., Colabufo, N. A., Contino, M., Perrone, M. G., Digiacomo, M. Perrone, R., et al. (2014). SAR study on Arylmethyloxyphenyl scaffold: looking for a P-gp nanomolar affinity. Eur. J. Med. Chem. 76, 558-566. doi: 10.1016/j.ejmech.2014.02.051

Oak, P. S., Kopp, F., Thakur, C., Ellwart, J. W., Rapp, U. R., Ullrich, A., et al. (2012). Combinatorial treatment of mammospheres with trastuzumab and salinomycin efficiently targets HER2-positve cancer cells and cancer stem cells. Int. J. Cancer 131, 2808-2019. doi: 10.1002/ijc.27595

Orfao, A., and Ruiz-Arguelles, A. (1996). General concepts about cell sorting techniques. Clin. Biochem. 29, 5-9. doi: 10.1016/0009-9120(95)02017-9

Park, J. T., Li, M., Nakayama, K., Mao, T. L., Davidson, B., Zhang, Z., et al. (2006). Notch3 gene amplification in ovarian cancer. Cancer Res. 66, 6312-6318. doi: 10.1158/0008-5472.CAN-05-3610

Patterson, L. H., Craven, M. R., Fisher, G. R., and Teesdale-Spittle P. (1994). Aliphatic amine N-oxides of DNA binding agents as bioreductive drugs. Oncol. Res. 6, 533-538.

Patterson, L. H., McKeown, S. R., Ruparelia, K., Double, J. A., Bibby, M. C., Cole, S., et al. (2000). Enhancement of chemotherapy and radiotherapy of murine tumours by $\mathrm{AQ} 4 \mathrm{~N}$, a bioreductively activated anti-tumour agent. Br. J. Cancer 82, 1984-1990. doi: 10.1054/bjoc.2000.1163

Perez-Tomas, R. (2006). Multidrug resistance: retrospect and prospects in anti-cancer drug treatment. Curr. Med. Chem. 13, 1859-1876. doi: 10.2174/092986706777585077

Perlia, C. P., Gubisch, N. J., Wolter, J., Edelberg, D., Dederick, M. M., and Taylor, S. G. 3rd. (1970). Mithramycin treatment of hypercalcemia. Cancer 25, 389-394. doi: 10.1002/1097-0142(197002)25:2<389::AIDCNCR2820250217>3.0.CO;2-X

Pharm, A. N., Penchala, S., Graf, R. A., Wang, J., and Huang, Y. (2008). "Pharmacogenomic characterization of ABC transporters involved in Multidrug Resistance," in Multidrug Resistance: Biological and Pharmaceutical Advance in the Antitumour Treatment, ed N. A. Colabufo (Kerala: Research Signpost), 19-62.

Phillips, R. M., Hendriks, H. R., and Peters, G. J. (2013). EO9 (Apaziquone): from the clinic to the laboratory and back again. Br. J. Pharmacol. 168, 11-18. doi: 10.1111/j.1476-5381.2012.01996.x

Pietras, A. (2011). Cancer stem cells in tumor heterogeneity. Adv. Cancer Res. 112, 255-281. doi: 10.1016/B978-0-12-387688-1.00009-0

Pollard, S. M., Yoshikawa, K., Clarke, I. D., Danovi, D., Stricker, S., Russell, R., et al. (2009). Glioma stem cell lines expanded in adherent culture have tumor-specific 
phenotypes and are suitable for chemical and genetic screens. Cell Stem Cell 4, 568-580. doi: 10.1016/j.stem.2009.03.014

Proske, D., Blank, M., Buhmann, R., and Resch, A. (2005). Aptamers-basic research drug development and clinical applications. Appl. Microbiol. Biotechnol. 69, 367-374. doi: 10.1007/s00253-005-0193-5

Rauth, A. M., Melo, T., and Misra, V. (1998). Bioreductive therapies: an overview of drugs and their mechanisms of action. Int. J. Radiat. Oncol. Biol. Phys. 42, 755-762. doi: 10.1016/S0360-3016(98)00302-2

Riccioni, R., Dupuis, M. L., Bernabei, M., Petrucci, E., Pasquini, L., Mariani, G., et al. (2010). The cancer stem cell selective inhibitor salinomycin is a P-glycoprotein inhibitor. Blood Cells Mol. Dis. 45, 16-92. doi: 10.1016/j.bcmd.2010.03.008

Ricci-Vitiani, L., Lombardi, D. G., Pilozzi, E., Biffoni, M., Todaro, M., Peschle, C., et al. (2007). Identification and expansion of human colon-cancer-initiating cells. Nature 445, 111-115. doi: 10.1038/nature05384

Riobo, N. A., Lu, K., Ai, X., Haines, G. M., and Emerson, C. P. Jr. (2006). Phosphoinositide 3-kinase and AKT are essential for Sonic Hedgehog signaling. Proc. Natl. Acad. Sci. U.S.A. 103, 4505-4510. doi: 10.1073/pnas.0504337103

Rischin, D., Peters, L. J., O’Sullivan, B., Giralt, J., Fisher, R., Yuen, K., et al. (2010). Tirapazamine, cisplatin, and radiation versus cisplatin and radiation for advanced squamous cell carcinoma of the head and neck (TROG 02.02, HeadSTART): a phase III trial of the Trans-Tasman Radiation Oncology Group. J. Clin. Oncol. 28, 2989-2995. 10.1200/JCO.2009.27.4449

Sagiv, E., Starr, A., Rozovski, U., Khosravi, R., Altevogt, P., Wang, T., et al. (2008). Targeting CD24 for treatment of colorectal and pancreatic cancer by monoclonal antibodies or small interfering RNA. Cancer Res. 68, 2803-2812. doi: 10.1158/0008-5472.CAN-07-6463

Sasaki, H., Nishizaki, Y., Hui, C., Nakafuku, M., and Kondoh, H. (1999). Regulation of Gli2 and Gli3 activities by an amino-terminal repression domain: implication of Gli2 and Gli3 as primary mediators of Shh signaling. Development 126, 3915-3924.

Saunders, M. P., Jaffar, M., Patterson, A. V., Nolan, J., Naylor, M. A., Phillips, R. M., et al. (2000). The relative importance of NADPH: cytochrome c (P450) reductase for determining the sensitivity of human tumour cells to the indolequinone EO9 and related analogues lacking functionality at the C-2 and C-3 positions. Biochem. Pharmacol. 59, 993-996. doi: 10.1016/S0006-2952(99)00405-0

Sefah, K., Shangguan, D., Xiong, X. L., O’Donoghue, M. B., and Tan, W. (2010). Development of DNA aptamers using Cell-SELEX. Nat. Protoc. 5, 1169-1185. doi: $10.1038 /$ nprot.2010.66

Shangguan, D., Li, Y., Tang, Z. W., Cao, Z. C., Chen, H. W., Mallikaratchy, P., et al. (2006). Aptamers evolved from live cells as effective molecular probes for cancer study. Proc. Natl. Acad. Sci. U.S.A. 103, 11838-11843. doi: 10.1073/pnas.0602615103

Shank, J. J., Yang, K., Ghannam, J., Cabrera, L., Johnston, C. J., Reynolds, R. K., et al. (2012). Metformin targets ovarian cancer stem cells in vitro and in vivo. Gynecol. Oncol. 127, 390-397. doi: 10.1016/j.ygyno.2012.07.115

Shinde, S. S., Maroz, A., Hay, M. P., Patterson, A. V., Denny, W. A., and Anderson, R. F. (2010). Characterization of radicals formed following enzymatic reduction of 3-substituted analogues of the hypoxia-selective cytotoxin 3-amino-1,2,4benzotriazine 1,4-dioxide (tirapazamine). J. Am. Chem. Soc. 132, 2591-2599. doi: $10.1021 /$ ja908689f

Siemann, D. W., and Keng, P. C. (1986). Cell cycle specific toxicity of the Hoechst 33342 stain in untreated or irradiated murine tumor cells. Cancer Res. 46, 3556-3559.

Singh, S. K., Clarke, I. D., Terasaki, M., Bonn, V. E., Hawkins, C., Squire, J., et al. (2003). Identification of a cancer stem cell in human brain tumors. Cancer Res. 63, 5821-5828.

Singleton, R. S., Guise, C. P., Ferry, D. M., Pullen, S. M., Dorie, M. J., Brown, J. M., et al. (2009). DNA crosslinks in human tumor cells exposed to the prodrug PR-104A: relationships to hypoxia, bioreductive metabolism and cytotoxicity. Cancer Res. 69, 3884-3891. doi: 10.1158/0008-5472.CAN-08-4023

Smith, K. M., Datti, A., Fujitani, M., Grinshtein, N., Zhang, L., Morozova, O., et al. (2010). Selective targeting of neuroblastoma tumour-initiating cells by compounds identified in stem cell-based small molecule screens. EMBO Mol. Med. 2, 371-384. doi: 10.1002/emmm.201000093

Smith, L. M., Nesterova, A., Ryan, M. C., Duniho, S., Jonas, M., Anderson, M., et al. (2008). CD133/prominin-1 is a potential therapeutic target for antibodydrug conjugates in hepatocellular and gastric cancers. Br. J. Cancer 99, 100-109. doi: 10.1038/sj.bjc. 6604437
Storms, R. W., Trujillo, A. P., Springer, J. B., Shah, L., Colvin, O. M., Ludeman, S. M., et al. (1999). Isolation of primitive human hematopoietic progenitors on the basis of aldehyde dehydrogenase activity. Proc. Natl. Acad. Sci. U.S.A. 96, 9118-9123. doi: 10.1073/pnas.96.16.9118

Stratford, E. W., Bostad, M., Castro, R., Skarpen, E., Berg, K., Høgset, A., et al. (2013). Photochemical internalization of CD133-targeting immunotoxins efficiently depletes sarcomacells with stem-like properties and reduces tumorigenicity. Biochim. Biophys. Acta 1830, 4235-4243. doi: 10.1016/j.bbagen.2013. 04.033

Su, Y., Qiu, Q., Zhang, X., Jiang, Z., Leng, Q., Liu, Z., et al. (2010). Aldehyde dehydrogenase $1 \mathrm{~A} 1$-positive cell population is enriched in tumor-initiating cells and associated with progression of bladder cancer. Cancer Epidemiol. Biomarkers Prev. 19, 327-337. doi: 10.1158/1055-9965.EPI-09-0865

Takaishi, S., Okumura, T., Tu, S., Wang, S. S., Shibata, W., Vigneshwaran, R., et al. (2009). Identification of gastric cancer stem cells using the cell surface marker CD44. Stem Cells 27, 1006-1020. doi: 10.1002/stem.30

Takebe, N., Harris, P. J., Warren, R. Q., and Ivy, S. P. (2011). Targeting cancer stem cells by inhibiting Wnt, Notch, and Hedgehog pathways. Nat. Rev. Clin. Oncol. 8, 97-106. doi: 10.1038/nrclinonc.2010.196

Tanaka, K., Okabayashi, K., Asashima, M., Perrimon, N., and Kadowaki, T. (2000). The evolutionarily conserved porcupine gene family is involved in the processing of the Wnt family. Eur. J. Biochem. 267, 4300-4311. doi: 10.1046/j.1432-1033.2000.01478.x

Tang, Q. L., Zhao, Z. Q., Li, J. C., Liang, Y., Yin, J. Q., Zou, C. Y., et al. (2011). Salinomycin inhibits osteosarcoma by targeting its tumor stem cells. Cancer Lett. 311, 113-121. doi: 10.1016/j.canlet.2011.07.016

Teng, Y., Wang, X., Wang, Y., and Ma, D. (2010). Wnt/ $\beta$-catenin signaling regulates cancer stem cells in lung cancer A549 cells. Biochem. Biophys. Res. Commun. 392, 373-379. doi: 10.1016/j.bbrc.2010.01.028

Teodori, E., Dei, S., Martelli, S., Scapecchi, F., and Gualtieri, F. (2006). The functions and structure of $\mathrm{ABC}$ transporters: implications for the design of new inhibitors of Pgp and MRP1 to control multidrug resistance (MDR). Curr. Drug Targets 7, 893-909. doi: 10.2174/138945006777709520

Thomas, T., Nowka, K., Lan, L., and Derwahl, M. (2006). Expression of endoderm stem cell markers: evidence for the presence of adult stem cells in human thyroid glands. Thyroid 16, 537-544. doi: 10.1089/thy.2006.16.537

Tomiyasu, S., Miyamoto, T., Mori, M., Yaguchi, T., Yakushiji, H., Ohno, S., et al. (2014). Isolation of side population cells from endometrial cancer cells using a violet laser diode. Hum. Cell 27, 36-42. doi: 10.1007/s13577-013-0079-2

Tuerk, C., and Gold, L. (1990). Systematic evolution of ligands by exponential enrichment-RNA ligands to bacteriophage-T4 DNA-polymerase. Science 249, 505-510. doi: 10.1126/science.2200121

Varjosalo, M., and Taipale, J. (2008). Hedgehog: functions and mechanisms. Genes Dev. 22, 2454-2472. doi: 10.1101/gad.1693608

Waaler, J., Machon, O., Tumova, L., Dinh, H., Korinek, V., Wilson, S. R., et al. (2012). A novel Tankyrase inhibitor decreases canonical Wnt signaling in colon carcinoma cells and reduces tumor growth in conditional APC mutant mice. Cancer Res. 72, 2822-2832. doi: 10.1158/0008-5472. CAN-11-3336

Waldron, N. N., Kaufman, D. S., Oh, S., Inde, Z., Hexum, M. K., Ohlfest, J. R., et al. (2011). Targeting tumor-initiating cancer cells with dCD133KDEL shows impressive tumor reductions in a xenotransplant model of human head and neck cancer. Mol. Cancer Ther. 10, 1829-1838. doi: 10.1158/1535-7163.MCT11-0206

Wang, S., Huang, S., Zhao, X., Zhang, Q., Wu, M., Sun, F., et al. (2013a). Enrichment of prostate cancer stem cells from primary prostate cancer cultures of biopsy samples. Int. J. Clin. Exp. Pathol. 7, 184-193.

Wang, X., Moon, J., Dodge, M. E., Pan, X., Zhang, L., Hanson, J. M., et al. (2013b). The development of highly potent inhibitors for porcupine. J. Med. Chem. 56, 2700-2704. doi: 10.1021/jm400159c

Wang, Y. (2011). Effects of salinomycin on cancer stem cell in human lung adenocarcinoma A549 cells. Med. Chem. 7, 206-111. doi: 10.2174/15734061179 4859307

Wang, Z., Li, Y., Kong, D., Banerjee, S., Ahmad, A., Azmi, A. S., et al. (2009). Acquisition of epithelialmesenchymal transition phenotype of gemcitabineresistant pancreatic cancer cells is linked with activation of the notch signaling pathway. Cancer Res. 69, 2400-2407. doi: 10.1158/0008-5472.CAN-08-4312

Whitworth, J. M., Londono-Joshi, A. I., Sellers, J. C., Oliver, P. J., Muccio, D. D., Atigadda, V. R., et al. (2012). The impact of novel retinoids in combination 
with platinum chemotherapy on ovarian cancer stem cells. Gynecol. Oncol. 125, 226-230. doi: 10.1016/j.ygyno.2011.12.425

Wintzell, M., Lofstedt, L., Johansson, J., Pedersen, A. B., Fuxe, J., and Shoshan, M. (2012). Repeated cisplatin treatment can lead to a multiresistant tumor cell population with stem cell features and sensitivity to 3-bromopyruvate. Cancer Biol. Ther. 13, 1454-1462. doi: 10.4161/cbt.22007

Wright, M. H., Calcagno, A. M., Salcido, C. D., Carlson, M. D., Ambudkar, S. V., and Varticovski, L. (2008). Brcal breast tumors contain distinct CD44+/CD24- and CD133+ cells with cancer stem cell characteristics. Breast Cancer Res. 10:R10. doi: 10.1186/bcr 1855

Xia, J., Zhang, Y., Qian, J., Zhu, X., Zhang, Y., Zhang, J., et al. (2013). Isolation, identification and expression of specific human CD133 antibodies. Sci. Rep. 3:3320. doi: $10.1038 /$ srep 03320

Xin, L. I., Lawson, D. A., and Witte, O. N. (2005). The Sca-1 cell surface marker enriches for a prostate-regenerating cell subpopulation that can initiate prostate tumorigenesis. Proc. Natl. Acad. Sci. U.S.A. 102, 6942-6947. doi: 10.1073/pnas.0502320102

Yang, X., Zheng, X., Cao, J., Xiang, H., Liu, F., and Lv, Y. (2010). 8bromo-7-methoxychrysin-induced apoptosis of hepatocellular carcinoma cells involves ROS and JNK. World J. Gastroenterol. 16, 27385-23393. doi: 10.3748/wjg.v16.i27.3385

Yasmeen, A., Beauchamp, M. C., Piura, E., Segal, E., Pollak, M., and Gotlieb, W. H. (2011). Induction of apoptosis by metformin in epithelial ovarian cancer: involvement of the Bcl-2 family proteins. Gynecol. Oncol. 121, 492-498. doi: 10.1016/j.ygyno.2011.02.021

Yeung, J., Esposito, M. T., Gandillet, A., Zeisig, B. B., Griessinger, E., Bonnet, D., et al. (2010). $\beta$-catenin mediates the establishment and drug resistance of MLL leukemic stem cells. Cancer Cell 18, 606-618. doi: 10.1016/j.ccr.2010.10.032

Yin, J., Glaser, R., and Gates, K. S. (2012). On there action mechanism of tirapazamine reduction chemistry: unimolecular $\mathrm{N}-\mathrm{OH}$ homolysis, stepwise dehydration, ortriazene ring-opening. Chem. Res. Toxicol. 25, 634-645. doi: $10.1021 /$ tx200546u

Yo, Y. T., Lin, Y. W., Wang, Y. C., Balch, C., Huang, R. L., Chan, M. W., et al. (2012). Growth inhibition of ovarian tumor-initiating cells by niclosamide. Mol. Cancer Ther. 11, 1703-1712. doi: 10.1158/1535-7163.MCT-12-0002

Zeman, E. M., Brown, J. M., Lemmon, M. J., Hirst, V. K., and Lee, W. W. (1986). SR-4233: a new bioreductive agent with high selective toxicity for hypoxic mammalian cells. Int. J. Radiat. Oncol. Biol. Phys. 12, 1239-1242. doi: 10.1016/03603016(86)90267-1
Zhang, S., Balch, C., Chan, M. W., Lai, H. C., Matei, D., Schilder, J. M., et al. (2008). Identification and characterization of ovarian cancer-initiating cells from primary human tumors. Cancer Res. 68, 4311-4320. doi: 10.1158/00085472.CAN-08-0364

Zhao, C., Chen, A., Jamieson, C. H., Fereshteh, M., Abrahamsson, A., Blum, J., et al. (2009). Hedgehog signaling is essential for maintenance of cancer stem cells in myeloid leukaemia. Nature 458, 776-779. doi: 10.1038/nature07737

Zhi, Q. M., Chen, X. H., Ji, J., Zhang, J. N., Li, J. F., Cai, Q., et al. (2011). Salinomycin can effectively kill ALDH(high) stem-like cells on gastric cancer. Biomed. Pharmacother. 65, 509-515. doi: 10.1016/j.biopha.2011.06.006

Zhou, F., Mu, Y. D., Liang, J., Liu, Z. X., Chen, H. S., and Zhang, J. F. (2014). Expression and prognostic value of tumor stem cell markers ALDH1 and CD133 in colorectal carcinoma. Oncol. Lett. 7, 507-512. doi: 10.3892/ol.2013.1723

Zhou, J., Wulfkuhle, J., Zhang, H., Gu, P., Yang, Y., Deng, J., et al. (2007). Activation of the PTEN/mTOR/STAT3 pathway in breast cancer stem-like cells is required for viability and maintenance. Proc. Natl. Acad. Sci. U.S.A. 104, 16158-16163. doi: 10.1073/pnas.0702596104

Zhou, J., Zhang, H., Gu, P., Bai, J., Margolick, J. B., and Zhang, Y. (2008). NF- $\mathrm{B}$ pathway inhibitors preferentially inhibit breast cancer stem-like cells. Breast Cancer Res. Treat. 111, 419-427. doi: 10.1007/s10549-0079798-y

Conflict of Interest Statement: The authors declare that the research was conducted in the absence of any commercial or financial relationships that could be construed as a potential conflict of interest.

Received: 31 March 2014; accepted: 20 June 2014; published online: 10 July 2014. Citation: Zinzi L, Contino M, Cantore M, Capparelli E, Leopoldo $M$ and Colabufo NA (2014) ABC transporters in CSCs membranes as a novel target for treating tumor relapse. Front. Pharmacol. 5:163. doi: 10.3389/fphar.2014.00163

This article was submitted to Pharmacology of Anti-Cancer Drugs, a section of the journal Frontiers in Pharmacology.

Copyright (c) 2014 Zinzi, Contino, Cantore, Capparelli, Leopoldo and Colabufo. This is an open-access article distributed under the terms of the Creative Commons Attribution License (CC BY). The use, distribution or reproduction in other forums is permitted, provided the original author(s) or licensor are credited and that the original publication in this journal is cited, in accordance with accepted academic practice. No use, distribution or reproduction is permitted which does not comply with these terms. 